\title{
Whose Power to Control? Some Reflections on Seed Systems and Food Security in a Changing World
}

\author{
Geoff Tansey
}

Abstract Four key words are essential in understanding the changing global food system: power, control, risks and benefits. The interplay between state and private actors vying to influence the direction of change, and use whatever tools for control they can, is at the heart of the contention for the future control of food. It is one shaped by history and influenced by a changing geopolitics. This interplay has led to the creation of a range of global rules affecting food, agriculture and biodiversity in which those on 'intellectual property' or IP are central. These rules come from a system dominated by the interests of the biggest players. Also important are the changing understandings and nature of food security and the pathways to innovation in agri-food systems that are most likely to lead to a just, healthy and sustainable future for all. Developments in food and farming are central to this and are the context in which the political economy of cereal seed systems in Africa is grounded.

\section{Questions arising}

The articles in this issue of the IDS Bulletin on 'The Politics of Seed in Africa's Green

Revolution' raise a number of questions for me:

- Where do seed systems fit and how important are they in creating a fair and sustainable food system that enables everyone to be well fed, especially given the changing understanding of food security, the global challenges facing humanity and the contested alternatives for meeting them?

- How far is it useful to talk of Africa as a whole, as opposed to the many and varied situations found in the different countries and agroecological contexts in this huge continent?

- Whose interests are being served in the current approaches to innovation, how grounded in local knowledge and conditions are these and how far will they meet the needs of those most affected by food and livelihood insecurity?

In Malawi, for example, Blessings Chinsinga (2010: 1) has observed:

The interests of seed companies, donors and government have... for different reasons, coincided to create a seed industry that has a very narrow product portfolio, distributes benefits to a very small proportion of the population through various forms of commercial ventures and schemes of political patronage buoyed by excessive weaknesses in the regulatory framework for the seed industry.

The level of formal and informal seed provision varies greatly between the different countries and for different crops within them. A tiny percentage of land is planted with 'formal' seed system seed in Ethiopia (Alemu, this IDS Bulletin) but a larger amount in other countries, with both formal and informal being important in Kenya (Odame and Muange, this IDS Bulletin). Moreover, in Ghana:

The formal seed system constructs farmers as passive recipients and end-users of certified seeds, and victims of their own poor quality seed that entrenches them in poverty. In reality, farmers are capable innovators and are actively involved in the multiplication of seed. (Amanor 2010: 23)

While the focus of this issue is on seed, which 'is perhaps the most important determinant of crop 
success or failure alongside fertiliser and water' (Chinsinga 2010: 1), this is just one factor among many to affect not just yield but the final availability of food (FAO 1992). In other words, there is a larger political economy in which changes in Africa's seed systems are occurring. One key element of this is a changed global framework of laws, rules and regulations that have been embedded in a series of international agreements, since the 1990s. These laws increasingly affect national policies and the strategies of key private actors. Moreover, some key agreements were shaped with little or no regard for the needs of small farmers and poor people, whether in Africa or elsewhere.

Reflecting on these larger global changes offers a lens through which to view developments in cereal seed systems in Africa and agri-food systems more generally.

\section{Power and history matter}

For me, there are four key words to reflect on when considering changes in the food system: power, control, risk and benefits (Tansey and Worsley 1995). There is a dynamic interplay among the different actors and interests in the food system which centres around who has what power to control their particular part of the system in ways that minimise risks and optimise benefits for themselves. Sometimes the reduction of risks and increase in benefits go together, such as for large, Northern-based supermarket chains, who profit by using their buyer power to drive down prices in the supply chain and demand standardised product delivery and consistent supply. In other cases, this relationship is less straightforward. Small farmers in sub-Saharan Africa, for example, usually develop complex farming systems and strategies that seek to minimise risk to life and livelihoods, often for modest benefits, but have little influence over the economic conditions in which they operate.

The food system depends upon a well-functioning biosphere for its productivity. Food and water fulfil the fundamental human need for subsistence (Max-Neef 1992). Human needs are complex and food meets them in various ways not just physiological but psychological, cultural, social and economic. Food also has a history - a history linked to human, imperial expansion and ecological mismanagement, the outcome of which may be different from that seen today (Fraser and Rimas 2010). This is clear from the different experiences of the five countries highlighted in this issue, which reflect different aspects of the exploitation of Africa as a source of raw materials and commodities needed by others beyond its borders. While history and context matter greatly in understanding the dynamics of today, and should inform how challenges are met, they do not fix the future.

\subsection{Tools for control}

There are various tools for control available for different private actors and states to use. These include the exercise of political, military and economic power; the use of science, technology, information and management; as well as the creation of laws, rules and regulations that frame what is permissible. Historically, as is well illustrated in the five country case studies, it has been the exercise of external, colonial, political and military power that shaped much of African agriculture, cropping patterns, commodity production and trade. For example, the colonial past shaped the framework within which the independent governments found themselves operating. The attempts to make fundamental changes to the existing farming structures in countries like Zimbabwe have both engendered considerable resistance and disruption but also created a new set of actors and farming systems requiring different kinds of support to function effectively (Mutonodzo-Davies and Magunda, this IDS Bulletin).

During the colonial era, the interest of those holding political power focussed on cash crops and commodities rather than food crops. Exotic crops became stable foods, such as maize and cassava. Local economies were devastated by the capture of people transported for slavery and boundaries drawn up for states as the colonial powers saw fit, not because they related to ecological or cultural patterns and local histories. Moreover, a model of what 'good' farming and animal husbandry was and what modernity meant emerged from 'the coloniser' and not 'the colonised'. This occurred both explicitly and implicitly through the acculturation of elites, through education and training and through emulation of industrial, input intensive - fossil fuel, fertiliser, pesticide, machinery - farming systems developed in Europe and North America. This model became and remains the dominant one for how farming should develop in Africa and elsewhere. 
During the twentieth century, and in particular since the end of World War II, these industrialised farming systems, serving progressively more urbanised populations, were supplied through, and sold products to, increasingly large firms. Formalised research systems, divorced from farming, developed. Plant-breeding left the farm and moved to the research station and professional breeder (see Lynam, this IDS Bulletin). It focused largely on commercial and commodity crops. These were produced for a set of ever larger food traders, manufacturers, processors, caterers and retailers, as a process of economic concentration of power developed. Over the last 20 years, that economic concentration of power has extended further and further into the seed business (Howard 2009; ETC Group 2005). From the mid- to late-twentieth century, public good breeding played a major role in producing cereal varieties that yielded well in response to fertiliser and water, and underpinned the 'Green Revolution' in Asia during the 1960s and 1970s and it continues to form the basis of current attempts to stimulate a similar agricultural revolution in Africa.

Despite these developments, the current food system is confronted by deep and profoundly troubling incongruities. While technological innovation has helped feed more people on the planet than ever before, the numbers of hungry remain stubbornly high, with over 900 million classified as food insecure, many of whom live in Africa (FAO 2010). At the same time, record numbers of people are overweight or obese or suffer from food-related chronic diseases or micronutrient deficiencies. These perverse and paradoxical trends reveal the tensions and contradictions in the modern food system. Nowhere is this more evident than in the seed sector, where legal rights over genetic material upon which agriculture is based are increasingly concentrated in the hands of a few at the expense of the many.

\section{Controlling seeds and intellectual property ${ }^{1}$}

Much of the focus in the discussion of seeds and plant-breeding is on their physical attributes and yield potentials. But as these case studies in this issue show, this is part of a much wider political economy of power and control. While technology has a role in this, other factors matter greatly as well. A key area is the rules that frame what the actors do. Here it is the changes that occurred at first in the USA and then other OECD countries that have come to be of global importance for food and farming, in particular for how the use of modern biotechnology, in particular genetic engineering (GE), is developing. While much debate focuses on the technology and what it may do, the key to the current corporate-driven use of genetic engineering is the law - specifically, laws on patents, plant variety protection and other forms of so-called 'intellectual property rights'. Changes in the law, initially in the USA in the 1980s and globally since then, helped draw agro-chemical companies, with their patentbased chemical business background, into the messy, long-winded art and science of plantbreeding.

So why do patents matter? What role do these intellectual property rights have? A patent is a privilege granted by a government, allowing the holder to exclude others from making, using, importing and selling an invention. Patents provide the holder with an effective monopoly on a particular product or production process. These privileges apply in the countries where they are granted for a limited period (the minimum is now 20 years). To prevent some patents from harming the public interest, governments retain the right to over-ride them in certain circumstances (using a 'compulsory licence').

\subsection{From America to the world}

Until the 1980 s, the use of patents in plantbreeding was very limited, basically only to the USA for certain kinds of plants. Europeans did not like the idea of using patents for plants, as they were too restrictive, in part because they prevented any others using the materials covered by the patent. The European view was also that it was not possible to describe the 'invention', as was required in patent law. Following pressure from the European seed industry, an alternative system for taking out some form of intellectual property protection over the plants the industry bred was developed for Europe - called 'Plant Breeders' Rights' (PBRs - under the UPOV Convention: the French acronym for the International Union for the Protection of New Varieties of Plants, adopted in 1961 and which came into force in 1968 once it had been ratified by three European countries). ${ }^{2}$ These PBRs were less restrictive than patents and allowed any breeder to use any other breeders' plants in breeding a new variety - a necessity as breeding 
is a very complex process involving crossing many different plants.

As the rules on PBRs were periodically revised, in 1972, 1978 and 1991, they extended the scope of this protection and made it more difficult for farmers to do what they always had, which was save, share and breed from their own seed if they wanted to. In Europe, the USA and some other OECD countries with commercial agriculture, farmers had gradually stopped doing this and only public and private breeders produced new varieties. None of this mattered very much to most African countries, where farmer-saved seed and breeding still mattered a lot, until the creation of the World Trade Organisation (WTO), when rules on intellectual property (IP) were included in the overall package of agreements countries had to sign up to on joining. With currently over 150 members and about 30 more queuing up to join, this makes the WTO rules more or less global.

\section{Technological control}

The advent of genetic engineering offered a short cut for agri-chemical firms to get into plant-breeding, to introduce traits, e.g. resistance to a herbicide they produced (and in some cases which was due to go off-patent, which meant a generic company could make it for a fraction of the cost and the profits of the firm with the patent would greatly decline) or to introduce a pesticide into a variety. But the problem with plants is that they reproduce themselves and firms wanted mechanisms to prevent farmers simply buying once and then replanting their own home-grown seed.

There are two approaches to getting such protection: via the law or technology fixes. Hybrid seeds are an example of a technologybased protection measure - they do not reproduce truly and you need to buy more hybrid seed every year. It is also possible to develop higher yielding open pollinated varieties but there is not the commercial incentive to do so, as farmers would not have to come back for more every year. The much talked about terminator or traitor technology, whereby plants are bred so their seeds are sterile or will only exhibit particular traits when triggered by the application of a chemical, are another kind of technological lock-in being developed for GE plants.

\section{Legal control}

The other way to control the market for seeds is to make it illegal for farmers to re-use seed without permission or payment. To achieve this required globally extending rules on intellectual property (IP) in agriculture. This happened through the inclusion of the Agreement on Trade-related Aspects of Intellectual Property Rights (TRIPS) into the core set of Agreements countries have to sign up to when they join the WTO. TRIPS was promoted by transnational corporations in four major business areas whose business model depends on strong IP rules: software, film, music and pharmaceuticals/life sciences (Sell 2003; Drahos 2002). With global markets, these businesses wanted global IP rules to stop people copying their products. The existing UN agency dealing with IP - the World Intellectual Property Organization (WIPO) had been unable to deliver global rules. Even if new rules were agreed in WIPO, member countries did not have to sign up to them, and most developing countries did not - indeed in seeking a new international economic order in the 1970s, developing countries sought to have the patent rules in the Paris Convention changed but failed. ${ }^{3}$ Strong minimum IP rules are generally not in their interest: 'kicking away the ladder' as Cambridge economist Ha Joon Chang (2002) calls it, preventing them doing what most existing rich countries did, i.e. copy each other to catch up and adopt variable IP rules to suit their own economic interests.

\section{TRIPS with everything}

The TRIPS Agreement requires all WTO members to allow the patenting of microorganisms, gives them the option to opt out of patenting plants and animals (which was opposed by the USA in the negotiations) but requires them all to have some form of effective plant variety protection rules. It does not, however, define the meaning of any of the terms used. This offers countries a degree of flexibility in interpretation, including not to allow the patenting of plants, animals or their parts and to define their own plant variety protection rules.

Not only did TRIPS have the advantage of making IP rules global, it also put them into a new kind of international institution - the WTO - that has a binding dispute settlement mechanism backed by sanctions. This is why TRIPS, and its impact on access to medicines in 
particular, has drawn strong resistance from developing countries and many NGOs (Roffe $e t$ al. 2006). These concerns almost derailed two WTO Ministerial conferences and led to an amendment to the TRIPS Agreement. But people only need medicines when ill; everyone needs food and TRIPS's impact and the extension of IP into agriculture has hardly begun to be felt in developing countries yet, as the rules are only slowly taking effect, as we can see from the case from Ghana reported by Amanor, in this IDS Bulletin.

These rules matter because IP is a key driver in determining who will have what wealth and power in the twenty-first century. IP underpins a business model for the future of agriculture and the food system that is corporate-led, that facilitates the concentration of economic power in fewer and fewer hands and has helped drive the merging of many seed businesses so that now just a few firms control ever greater shares of the market (Howard 2010). 'The six largest agrochemical and seed corporations are filing sweeping, multi-genome patents in pursuit of exclusive monopoly over plant gene sequences that could lead to control of the world's plant biomass - whether it is used for food, feed, fiber, fuel or plastics', according to the ETC Group (2010).

IP is the key legal tool the major corporate players need to be involved in GE. Without rewriting and extending the rules on intellectual property, GE would not go away but how it was being developed, what it was being applied to and the balance of public vs private interests would be very different. It would probably play a much less important role in the range of biotechnological techniques that can be used to improve plantbreeding, such as marker assisted selection (MAS), which has already led the way to development of drought resistant crops. However, adding a patent-protected gene into varieties bred using MAS, in jurisdictions where patents are allowed on genes or plants, gives companies far greater control over the use of the crop.

Today, it may be best to think of the IP rules as facilitating a global private system of taxation as firms controlling key patents, copyright and trademarks, can set prices at levels far above costs and use them to segment markets, so as to extract as much as possible from each while preventing lower priced products in one area leaking out to places where they may charge many times more in another (Drahos 2010).

Intellectual property is one of the drivers of the bigger economic systems within which are many, often complex niches. For economists, key drivers of change are institutions and institutional arrangements. Property rights are at the centre of these, they determine who controls resources, who does and does not have access, and therefore how resources are used. Ecologists say we can't control ecosystems, but can affect them. An economist doesn't think like that but thinks property rights create efficiencies. Economists push systems to dangerous tipping points, to the edge of sustainability from an ecological point of view, as it is about maximization of resource use. It is this view of efficiency that dominates IP - maximise use of resources. What we need is an ecological view of property rights, less an efficiency view, if we want sustainable systems'. (Drahos 2008)

The detailed rules on IP, as developed in TRIPS and WIPO, are complex - as are their interactions with others' international agreements and these are discussed in detail elsewhere (Tansey and Rajotte 2008). But negotiations about IP have had spill-over effects on negotiations on biodiversity in the Convention on Biological Diversity (CBD) and on plant genetic resources for food and agriculture in UN's Food and Agriculture Organisation. They have poisoned the atmosphere in these other negotiations on various occasions because the kind of new enclosures being promoted by developed countries through the expansion of IP in TRIPS led to responses in these other fora that may make it more difficult for them to achieve their objectives. Even where so-called 'Farmers' Rights' - including rights to save, use, exchange and sell farm-saved seed/propagating material - have been included in the International Treaty on Plant Genetic Resources for Food and Agriculture (ITPGRFA), their formulation is much weaker than that which applies to IP.

\section{Challenges and opportunities}

This changing international framework, alongside rapidly developing technological innovation poses particular challenges for African states seeking to improve their food systems to make them more resilient, productive and 
equitable. The central question is, which kind of future are they seeking to create? Solutions to food security problems that are essentially to do with poverty and powerlessness of key constituencies cannot be solved by technical solutions focussed on seed alone. Innovation is needed that enables poor people and farmers to improve their livelihoods. As Riches (2003) notes people need livelihoods that provide sufficient income to enable purchase where necessary, or the possibility of self-provisioning where appropriate, not a system which keeps food artificially 'cheap' nor methods of food distribution which take away all dignity. The question is how does seed system development feed into what kind of innovation and for whom? That question takes us into the issue of the kind of future people want and what kind of innovation is needed for what kind of future.

\subsection{Redefining food security}

Since 1945, many different definitions of food security have emerged (Shaw 2007). In the mid1970s, one focus was on grain reserves: 'The concept of food security is broad and complex but its cornerstone is a system of grain reserves that will protect the world against the effects of violent fluctuations in food production and food prices'. ${ }^{4}$ By 1996, at the FAO Food Summit in Rome, food security was defined as: 'A situation that exists when all people, at all times, have physical, social and economic access to sufficient, safe and nutritious food that meets their dietary needs and food preferences for an active and healthy life'. This definition largely prevails at international and national levels. This usually leads to framing food security in terms of accessibility, availability and affordability (DEFRA 2008). However, this understanding neglects how food is produced and distributed and the sustainability of those systems; how food is made affordable and any subjective indicators of confidence such as the absence of fear and anxiety about where the next meal will come from and when, and confidence in continuity and sustainability (Maxwell 1996).

By the late 2000s, some started to stress that food security (Sustainable Development Commission 2009: 10) requires genuinely sustainable food systems:

- Where the core goal is clear: to feed everyone sustainably, equitably and healthily
- Which address availability, affordability and accessibility

- Which are diverse, ecologically-sound and resilient

- Which build capabilities and skills needed for future generations.

Nevertheless, even this framing misses the crucial aspects of who has what power and control in the system. Any approaches that ignore power, control and distributional aspects of change tend to fail the poorest people. In Latin America, for example, rural poverty persists, despite agricultural growth, according to a report from the FAO and the UN Economic Commission for Latin America and the Caribbean. ${ }^{5}$ These concerns have increasingly been highlighted by peasants' movements and smallholder farmers around the world, since the 1996 World Food Summit - the very people who are being squeezed out by the way agricultural development has been practiced to date. These groups seek food sovereignty, which combines: 'the right of peoples to healthy and culturally appropriate food produced through ecologically sound and sustainable methods, and their right to define their own food and agriculture systems' (Declaration of Nyéléni 2007).

In part, the peasants' movements are responding to approaches to subsidies, consumption patterns, misdirected and declining agricultural $\mathrm{R} \& \mathrm{D}$ and extension, and the growing concentration of power in the food system since the 1970s that have made the situation worse for many rural people and small farmers. They also reject the view that small farmers are an anachronism to be swept away with farming everywhere being modelled on the industrialised agriculture pattern in the main OECD countries. It is only by bringing these different understandings together, and recognising the complexity involved, as well as the power relations implied, that we can understand the role that cereal seed systems play in the bigger challenges of ensuring well-fed populations.

\subsection{Controlling power}

Some food and seed security challenges come from finding the right legal framework that suits the development objectives of the different states. All the five case study countries whose seed systems have been analysed in this issue have ratified or acceded to the $\mathrm{CBD}$ and its Biosafety 
Protocol and to the ITPGRFA. All but Ethiopia are WTO members. Thus far, however, only one, Kenya, has signed up to UPOV, and then in its less stringent 1978 version. ${ }^{6}$ This gives these countries (and many others in Africa not formally in UPOV) considerable scope to shape their own plant variety regimes and seed laws if they have the capacity and strength to use the flexibilities available to frame rules in ways that will support resilient, empowered farming communities.

As the various case studies in this issue suggest, there is a need for a broader mind set with which to look at the development of cereal seed systems, the future of farming and role of small farmers within this. Furthermore, there is a need to exchange experience between and among disciplines and countries, not just from within Africa - such as experience from China, with researchers and extension workers working with women and men in indigenous communities with participatory plant-breeding to improve maize varieties (Song and Vernooy 2010). This work seems to have addressed some of the key problems identified with the way research has frequently failed small farmers (Harwood 2009). Sometimes in the past it was because the agricultural research and development (R\&D) was too technocratic and failed to take account of the political and economic conditions of such farmers. Sometimes it was because of the way such R\&D was conceived, with arrogant and condescending attitudes common among experts who did the R\&D but who rarely had a rural farming background or understanding. In other cases, commercial entities opposed R\&D that farmers could easily copy or breed from, since this would reduce the market for their products.

There may also be opportunities to explore new approaches to ensure 'seed sovereignty' through restrictions on patentability. Use of biological open source forms of plant variety protection might also be explored, such as use of a general public licence for germplasm to promote sharing of improved seed and its further development and inhibit control of seed by a few corporations using a mix of the patent or PBR system (Kloppenburg 2010). As the International Plant Genetics Research Institute (now Bioversity International) noted, 'There is not one ideal sui generis system that will suit the needs of all countries'. Moreover, 'a strong private sector requires a robust public sector to keep options available and to focus on the needs of marginal areas' (IPGRI 1999).

No WTO member needs to join UPOV to implement its obligations on plant variety protection and for countries with large informal sectors also keen to protect Farmers' Rights, it makes sense to have differentiated rules for formal and informal seed sectors as well as ensuring more than one alternative is available to farmers. For those developing countries who are members of UPOV, such as Kenya, there is an opportunity to help shape the next revision of the convention to better serve the varied farming systems and conform to a more complex international systems that recognises Farmers' Rights (Dutfield 2011: 19).

Other challenges arise in dealing with the use of biotechnology in seeds development. Otero (2008: 2) argues that in Latin America, 'regional and social polarization is already taking place at an accelerated pace with the introduction of agricultural biotechnology'. McAfee (2008: 65) also notes that 'like all technologies, crop varieties are co-creations by people and nature, a dynamic nexus of agrarian cultures and ecosystems of which they are a part. This relationship is little appreciated by most proponents of transgenics'. She also recognises the complexity of cultural, economic and political factors that are involved in overcoming hunger. These include land reform, farmercentred research and extension, low-interest credit and assistance with storage, transport and marketing. But, she comments (2008: 83), 'in most policy circles, it seems, obstacles to such changes appear far more daunting than the prospect of curing hunger by manipulating molecules', an observation of relevance to the country cases highlighted in this IDS Bulletin.

\subsection{Rethinking innovation}

In approaching future developments of the cereal seeds systems in Africa, I think it is prudent to avoid a few mega-firms dominating, not just seed but throughout the food system, in which the trend has been for an ever-increasing economic concentration of power. At a time when the world faces the range of complex challenges - from increasing climate change to competition for land, water and energy resources and from growing inequality to rapid urbanisation - it seems we have moved internationally in the 
wrong direction with the ever expanding reach of the current Intellectual Property regime and its extension into agriculture, which has been the quintessential open source system of innovation, grounded in the local environment and sharing and exchanging materials and experience. A focus on what may be protected by IP induces innovation focussed on technological inputs rather than institutional, social and economic changes and altered power relationships, which are key to achieving a well-fed world. Instead, the new institutional arrangements promote wide dissemination of broadly adapted varieties controlled by a few firms that feed into industrialised systems of farming. It is not too late to change, or for many African countries to avoid this. In other fields, e.g. medicines and software, this model is being challenged. Why then go further down an IP-based road for food and farming when what is at stake is not just the future control of food, but who will have access to what food - indeed, possibly who will eat?

Embracing a smart, ecological, equitable approach to the food system, one that focuses on a different agro-ecological, complex, cyclical farming systems and builds on open, disseminated systems of innovation, requires a radical shift in R\&D and extension focus and capacities (NAS 2010; IAASTD 2008). Tensions related to this are evident in many of the articles

\section{Notes}

1 The issues in this section are discussed in far more detail in Tansey and Rajotte (2008), and the references can be found there.

2 The International Union for the Protection of New Varieties of Plants (UPOV) is an intergovernmental organisation with headquarters in Geneva, Switzerland. UPOV was established by the International Convention for the Protection of New Varieties of Plants. The objective of the Convention, which was adopted in Paris in 1961 and revised three times since then, is the protection of new varieties of plants by an intellectual property right. For details, see: in this IDS Bulletin. Ultimately, there is a basic tension between IP and biodiversity that those in favour of global IP standards have failed or refused to discuss. IP owners do best (in terms of profit) if they have a global standard or product (Windows, Viagra, Roundup, etc.) that is protected globally by high IP standards. Yet, innovation in food and agriculture does best if it can draw on a rich biodiversity that depends on fragile variables such as traditional knowledge, local farming systems and easy exchange of materials. It builds on the open disseminated systems of innovation that underpin farming. Such systems have now been embraced by many in the computer and internet digital world. This approach promotes participatory plant-breeding, integrated pest management, organic or low external input farming, higher skilled, open systems of exchange, family-farm-based biodiverse farming, healthy diets, and keep cooking and farming skills alive from farm to home. By building a property rights system that rewards standardisation and homogeneity, we affect those variables that underpin our systems of biodiversity and the capacity of local farmers to control and develop their core raw materials, the seeds and animals they use.

What I take from the issues raised in this IDS Bulletin is that, not only is another way needed but it is possible - just more difficult.

www.upov.int/index_en.html (accessed 14 April 2011).

3 The Paris Convention for the Protection of Industrial Property, originally signed in 1883, was one of the first treaties to deal with intellectual property. The Convention now has over 170 contracting member countries.

4 'Food Security - Not Yet' (1976) Comment, Food Policy 1.4, August: 270.

5 As reported in: http://en.mercopress.com/ 2010/11/08/rural-poverty-remains-strong-inlatin-america-in-spite-of-agriculture-boom (accessed 15 April 2011).

6 Membership details based on information on each of the relevant body's website. 


\section{References}

Amanor, K.S. (2010) Participation,

Commercialisation and Actor Networks: The Political Economy of Cereal Seeds Systems in Ghana, Futures Agriculture Working Paper 16, Brighton: IDS

Chang, H-J. (2002) Kicking Away the LadderDevelopment Strategy in Historical Perspective, London: Anthem Press

Chinsinga, B. (2010) Seeds and Subsidies: The Political Economy of Input Programmes in Malawi, Futures Agriculture Working Paper 13, Brighton: IDS

Declaration of Nyéléni (2007) in UK Food Group briefing (2010) Securing Future Food: Towards Ecological Food Provision, London, www.ukfg.org.uk/ecological_food_provision.ph p (accessed 10 November 2010)

Defra (2008) Ensuring the UK's Food Security in a Changing World, London: Defra, www.defra.gov.uk/foodrin/pdf/Ensuring-UKFood-Security-in-a-changing-world-170708.pdf (accessed 15 April 2011)

Drahos, P. (2010) The Global Governance of Knowledge: Patent Offices and their Clients, Cambridge: Cambridge University Press

Drahos, P. (2008) 'For Good or for Greed?', Quote taken from Tansey, G. The Ecologist November: 29

Drahos, P. with Braithwaite, J. (2002) Information Feudalism - Who owns the Knowledge Economy, London: Earthscan

Dutfield, G. (2011) Food, Biological Diversity and Intellectual Property: The Role of the International Union for the Protection of New Varieties of Plants (UPOV), Global Economic Issues Publications, Intellectual Property Issue Paper 9, Geneva: Quaker United Nations Office, available at www.quno.org/economicissues/foodsustainability/foodLinks.htm\#QUNOPUB (accessed 28 April 2011)

ETC Group (2010) Gene Giants Stockpile Patents on 'Climate-ready' Crop in Bid to Become Biomasters, Communiqué 106, Ottawa, www.etcgroup.org/en/node/5221 (accessed 18 February 2011)

ETC Group (2005) Global Seed Industry Concentration - 2005, Communiqué 90, Ottawa, www.etcgroup.org/en/node/48, (accessed 15 February 2011)

FAO (2010) The State of Food Insecurity in the World, Rome: FAO

FAO (1992) Food and Nutrition: Creating a Well-fed World, Rome: FAO
Fraser, E.D.G. and Rimas, A. (2010) Empires of Food: Feast, Famine, and the Rise and Fall of Civilizations, New York: Random House

Harwood, J. (2009) 'Why have Green Revolutions so often Failed to Help Peasant-farmers?' paper prepared for the colloquium of the Agrarian Studies Program, Yale University, 9 October

Howard, P.H. (2009) 'Visualizing Consolidation in the Global Seed Industry: 1996-2008', Sustainability 1.4: 1266-87

IAASTD - International Assessment of Agricultural Knowledge, Science and Technology for Development (2008) Agriculture at the Crossroads, Washington DC: IAASTD www.agassessment.org/ (accessed 15 February 2011)

IPGRI (1999) Key Questions for Decision-Makers: Protection of Plant Varieties under the WTP Agreement on Trade-Related Aspects of Intellectual Property Rights, Rome: International Plant Genetic Resources Institute

Kloppenburg, J. (2010) 'Impending Dispossession, Enabling Repossession: Biological Open Source and the Recovery of Seed Sovereignty', Journal of Agrarian Change 10.3: 367-88

Max-Neef, M. (1992) 'Development and Human Needs', in P. Ekins and M. Max-Neef (eds), Real-Life Economics - Understanding Wealth Creation, London: Routledge

Maxwell, S. (1996) 'Food Security: A Postmodern Perspective', Food Policy 21.2: 155-70

McAfee, K. (2008) 'Exporting Crop Biotechnology: The Myth of molecular Miracles', in G. Otero (ed.), Food for the Few: Neoliberal Globalism and Biotechnology in Latin America, Austin: University of Texas Press

NAS - National Academy of Sciences (2010) Toward Sustainable Agricultural Systems in the 21st Century, Washington DC, http://dels.nas.edu/ Report/Toward-Sustainable-AgriculturalSystems/12832 (accessed 15 April 2011)

Otero, G. (2008) 'Neoliberal Globalism and the Biotechnology Revolution: Economic and Historical Context', in G. Otero (ed.), Food for the Few: Neoliberal Globalism and Biotechnology in Latin America, Austin: University of Texas Press

Riches, G. (2003) The Human Right to Food: Engaging the Debate about Globalization, Employment and the Quality of Life, paper for FAO Right to Food, www.fao.org/eims/ secretariat/right_to_food/eims_search/details. 
asp?lang=en\&pub_id $=213064$ (accessed 15 April 2011)

Roffe, P.; Tansey, G. and Vivas-Eugui, D. (2006) Negotiating Health: Intellectual Property and Access to Medicines, London: Earthscan

Shaw, D.J. (2007) World Food Security: A History Since 1945, Basingstoke: Palgrave Macmillan

Sell, S. K. (2003) Private Power, Public Law: The Globalization of Intellectual Property Rights, Cambridge: Cambridge University Press

Song, Y. and Vernooy, R. (2010) Seeds and Synergies: Innovating Rural Development in China, London: Practical Action and IDRC
Sustainable Development Commission (2009) Food Security and Sustainability: The Perfect Fit, SDC Position Paper, London: UK SDC

Tansey, G. and Rajotte, T. (2008) The Future Control of Food - A Guide to International Negotiations and Rules on Intellectual Property, Biodiversity and Food Security, London: Earthscan; also available online in English, www.idrc.ca/openebooks/397-3/ (accessed 15 April 2011)

Tansey, G. and Worsley, T. (1995) The Food System: A User's Guide, London: Earthscan 